\title{
Tipe Kerusakan Spora Myxobolus koi Pada Penyimpanan Dengan Berbagai Bahan Kimia
}

\author{
Gunanti Mahasri $^{1 *}$, Agus Nazaruddin Yahya ${ }^{2}$, Boedi Setya Rahardja', Moch Saad ${ }^{3}$, \\ Nanuk Qomariyah ${ }^{3}$
}

${ }^{1}$ Departemen Manajemen Kesehatan Ikan dan Budidaya Perairan, Fakultas Perikanan dan Kelautan Universitas

Airlangga, Kampus C UNAIR - Mulyorejo, Surabaya - 60115

${ }^{2}$ Budidaya Perairan, Fakultas Perikanan dan Kelautan Universitas Airlangga, Kampus C

UNAIR - Mulyorejo, Surabaya - 60115

${ }^{3}$ Fakultas Perikanan Universitas Islam Lamongan, Jl. Veteran no. 53A Lamongan

Phone/Fax. 0322_324706

*Corresponding Author : mahasritot@gmail.com

\begin{abstract}
Abstrak
Myxobolus koi merupakan parasit yang menyebabkan penyakit Myxobolusis pada ikan. Parasit ini sangat sulit ditangani dengan prevalensi mencapai $91 \%$ sehingga perlu dilakukan kajian terhadap parasit Myxobolus koi. Kerusakan spora merupakan salah satu kendala dalam pengembangan penelitian tentang pengendalian penyakit ini. Spora Myxobolus koi dapat mengalami kerusakan apabila disimpan dalam kondisi penyimpanan yang kurang baik. Kerusakan spora Myxobolus koi ini dipengaruhi oleh berbagai faktor diantaranya suhu dan bahan kimia. Bahan kimia merupakan media yang biasa digunakan untuk proses pengawetan. Beberapa bahan kimia yang dapat digunakan untuk menyimpan spora adalah alkohol, formaldehid, dan kalium bikromat. Penelitian ini bertujuan untuk mengetahui pengaruh bahan kimia pengawet terhadap kerusakan spora dan untuk mengetahui bahan kimia yang paling efektif mengawetkan spora selama proses penyimpanan. Penelitian ini menggunakan metode eksperimental dengan Rancangan Acak Lengkap (RAL) sebagai rancangan percobaan. Perlakuan yang digunakan adalah penyimpanan spora Myxobolus koi pada alkohol $70 \%$, formaldehid $0,1 \%$, dan kalium bikromat 2\%, dengan ulangan sebanyak 6 kali. Penyimpanan ini dilakukan selama 30 hari. Parameter utama yang diamati adalah persentase kerusakan spora Myxobolus. Data yang diperoleh kemudian di analisis menggunakan ANAVA (Analisis Varian).

Hasil penyimpanan spora menggunakan alkohol $70 \%\left(\mathrm{C}_{2} \mathrm{H}_{6} \mathrm{O}\right)$, formaldehida $0,1 \%\left(\mathrm{CH}_{2} \mathrm{O}\right)$, dan kalium bikromat 2\% $\left(\mathrm{K}_{2} \mathrm{Cr}_{2} \mathrm{O}_{7}\right)$ selama 30 hari menunjukkan tingkat kerusakan spora yang tidak berbeda nyata di setiap perlakuan yang berarti ketiga perlakuan atau ketiga bahan kimia dapat mengawetkan spora
\end{abstract}

Kata Kunci : penyimpanan, bahan kimia, kerusakan, Myxobolus koi

\section{PENDAHULUAN}

Myxobolus koi merupakan spesies dari protozoa yang menyebabkan penyakit Myxobolusis pada ikan. Kebanyakan infeksi parasit ini pada ikan dapat menimbulkan masalah ringan seperti timbulnya nodul pada insang, namun infeksi berat dapat menjadikan masalah serius dalam budidaya, khususnya bagi ikan muda (Klinger and Floyd, 2009). Bentuk spora Myxobolus koi seperti buah pir atau biji semangka yang terbungkus dalam nodul yang berisi ribuan spora (Anshary, 2008).

Myxobolus koi merupakan parasit yang berbahaya dan sulit untuk ditangani dengan prevalensi mencapai $91 \%$ (Rukyani, 1990). Hal tersebut menunjukkan bahwa Myxobolus koi dapat merugikan dan berbahaya bagi usaha budidaya terutama pada usaha pembenihan, sehingga perlu dilakukan kajian terhadap parasit Myxobolus koi. 
Kerusakan spora merupakan salah satu kendala dalam pengembangan penelitian tentang pengendalian penyakit ini. Spora Myxobolus koi dapat mengalami kerusakan apabila disimpan dalam kondisi penyimpanan yang kurang baik. Kerusakan spora Myxobolus koi ini dipengaruhi oleh berbagai faktor diantaranya suhu dan bahan kimia. Pengembangan penelitian tentang kerusakan spora Myxobolus merupakan hal penting karena kurangnya sumber yang menjelaskan tentang cara menangani kerusakannya dan sebagai acuan untuk penelitian lebih lanjut tentang pengendalian parasit tersebut. Penyimpanan spora bertujuan agar spora tahan lebih lama untuk keperluan penelitian lebih lanjut tentang parasit ini. Bahan kimia merupakan media yang biasa digunakan untuk proses pengawetan. Beberapa bahan kimia yang dapat digunakan untuk menyimpan spora adalah alkohol, formaldehid, dan kalium bikromat. Alkohol dan formaldehid mempunyai sifat fiksatif karena memiliki daya dehidrasi yang menyebabkan pengerasan sel atau jaringan (Nowacek, 2012), sedangkan kalium bikromat adalah larutan oksidator dan fiksatif yang memiliki daya penetrasi sehingga dapat mengawetkan nucleus dan mitokondria (Casselman, 1955). Pada penelitian ini spora Myxobolus koi akan disimpan menggunakan berbagai bahan kimia di atas dan diidentifikasi pengaruh bahan kimia tersebut terhadap spora Myxobolus koi. Kurangnya sumber yang menjelaskan tentang cara pengawetan spora pada penyimpanan dan sebagai acuan untuk penelitian lebih lanjut tentang pengendalian parasit ini, penelitian ini dilakukan dengan harapan dapat menjadi solusi dari masalah yang telah dijelaskan di atas.

\section{METODOLOGI PENELITIAN}

\section{Tempat dan Waktu Penelitian}

Penelitian ini dilaksanakan di Laboratorium Pendidikan Fakultas Perikanan dan Kelautan Universitas
Airlangga Surabaya. Penelitian ini dilaksanakan pada bulan Juni -Juli 2016.

\section{Alat dan Bahan Penelitian}

Peralatan penelitian yang dibutuhkan antara lain nampan bedah, cawan petri, mikroskop cahaya, pinset, gunting bedah, scalpel, tabung reaksi, gelas ukur, pipet, kertas label, Haemacytometer, object glass, cover glass, beaker glass, microtube, Counter. Bahan yang digunakan dalam penelitian ini adalah Spora Myxobolus koi didapat dari ikan koi yang positif terinfeksi Myxobolus koi, Phosphate Buffered Saline (PBS), alkohol $70 \%\left(\mathrm{C}_{2} \mathrm{H}_{6} \mathrm{O}\right)$, formaldehid $0,1 \%\left(\mathrm{CH}_{2} \mathrm{O}\right)$, dan kalium bikromat $2 \%$ $\left(\mathrm{K}_{2} \mathrm{Cr}_{2} \mathrm{O}_{7}\right)$, Aquadest dan minyak emersi.

\section{Prosedur kerja}

Ikan yang positif terinfeksi Myxobolus koi dibersihkan dengan air, lalu spora diambil dengan cara mengambil nodul pada insang ikan koi dengan menggunakan pinset dan scapel secara perlahan agar tidak pecah. Nodul diletakkan dalam cawan petri berisi aquadest lalu dipotong beberapa bagian untuk mengeluarkan spora, ditambah dengan air dan di dihitung. Penghitungan spora dilakukan dengan cara mengambil endapan dengan pipet sebanyak 1 tetes pada parit kaca haemocytometer yang telah diberi cover glass di atasnya dan dibiarkan sebentar agar larutan menyebar rata ke seluruh ruang. Setelah itu memulai penghitungan dengan metode big block yaitu penghitungan menggunakan petak empat besar. Hasil dari masing - masing petak (nA, nB, nC, $\mathrm{nD})$ tersebut dijumlahkan dan dibagi empat, hasil pembagian dikalikan dengan 10.000 (Mahasri dalam Titis, 2009). 


$$
\text { Kepadatan spora } / \mathrm{ml}=\frac{n A+n B+n C+n D}{4} \times 10.000
$$

Keterangan :

$\mathrm{nA}, \mathrm{nB}, \mathrm{nC}, \mathrm{nD}=$ jumlah spora pada blok $\mathrm{A}, \mathrm{B}, \mathrm{C}, \mathrm{D} ; 4=$ jumlah blok yang dihitung.

Setelah diketahui jumlah spora maka dilakukan pengenceran, hingga didapatkan jumlah spora sebanyak 200 spora/ml. Pengenceran dilakukan dengan rumus : $M 1 . V 1=M 2 . V 2$ keterangan : M1 $=$ konsentrasi awal, $\mathrm{V} 1=$ volume konsentrasi awal, M2 = konsentrasi yang dikehendaki, V2 = volume dari konsentrasi yang dikehendaki.

Spora Myxobolus koi yang telah dipreparasi dan diseleksi kemudian dimasukkan kedalam microtube sejumlah 3 perlakuan dan 6 ulangan. Setelah itu spora di simpan dalam 3 perlakuan yakni perlakuan alkohol $70 \%$, formaldehid 0,1\%, dan kalium bikromat $2 \%$. Penyimpanan ini dilakukan selama 30 hari. Jumlah spora pada tiap perlakuan adalah 200 spora.

Pengamatan kerusakan spora Myxobolus dilakukan dengan perbesaran 1000x dan ditambah minyak imersi. Data yang diambil adalah total spora Myxobolus yang dalam keadaan rusak dan dinyatakan dalam bentuk persentase. Parameter utama yang diamati adalah persentase spora Myxobolus yang rusak. Parameter penunjang adalah tipe kerusakan spora Myxobolus koi.

\section{Prosedur Uji}

Rancangan yang digunakan dalam penelitian ini adalah Rancangan Acak Lengkap (RAL) yang dilakukan secara eksperimental. Penelitian ini terdiri dari tiga perlakuan, yakni : A perlakuan alkohol 70\%, B perlakuan formaldehid $0,1 \%, \mathrm{C}$ perlakuan kalium bikromat $2 \%$ dengan 6 kali ulangan, sehingga terdapat 18 sampel perlakuan yakni A1, A2, A3, A4, A5, A6, B1, B2, B3, B4, B5, B6, C1, $\mathrm{C} 2, \mathrm{C} 3, \mathrm{C} 4, \mathrm{C} 5, \mathrm{C} 6$.

Data yang didapatkan berupa persentase spora Myxobolus yang rusak.
Data tersebut kemudian dianalisis menggunakan Analysis of Varian (ANOVA).

\section{HASIL DAN PEMBAHASAN \\ Kerusakan Spora Myxobolus koi}

Penyimpanan spora Myxobolus koi pada beberapa bahan kimia : alkohol $70 \%$ $\left(\mathrm{C}_{2} \mathrm{H}_{6} \mathrm{O}\right)$, formaldehida $0,1 \%\left(\mathrm{CH}_{2} \mathrm{O}\right)$, dan kalium bikromat $2 \%\left(\mathrm{~K}_{2} \mathrm{Cr}_{2} \mathrm{O}_{7}\right)$ bertujuan untuk menghambat proses kerusakan yang terjadi pada spora sehingga morfologi spora dapat dipertahankan secara utuh dalam waktu yang lebih lama dari keadaan normal.

Penghitungan kerusakan dilakukan di hari ke-30. Hasil pemeriksaan menunjukkan terjadi kerusakan pada ketiga perlakuan yang diberikan. Pada perlakuan alkohol $70 \%$ dan formaldehid $0,1 \%$ mayoritas spora mengalami pengerutan (gambar b). Lain halnya dengan kerusakan yang ditemukan pada perlakuan kalium bikromat 2\%. Pada perlakuan kalium bikromat $2 \%$ spora tidak terjadi pengerutan seperti yang terjadi pada perlakuan alkohol $70 \%$ dan formaldehid $0,1 \%$. Kerusakan yang terjadi berupa kapsul polar yang mengalami dislokasi atau hancur (gambar c) dan beberapa spora kosong atau tidak berisi (gambar d).

\section{Penghitungan Persentase Kerusakan Spora Myxobolus koi}

Setelah proses penyimpanan spora selama 30 hari didapatkan data kerusakan spora, spora yang masih utuh dan persentase kerusakan spora seperti yang terlihat pada tabel 1. Data yang diperoleh kemudian di analisis menggunakan ANAVA (Analisis Varian) untuk mengetahui apakah terdapat perbedaan dari ketiga bahan kimia terhadap kerusakan spora Myxobolus koi. 

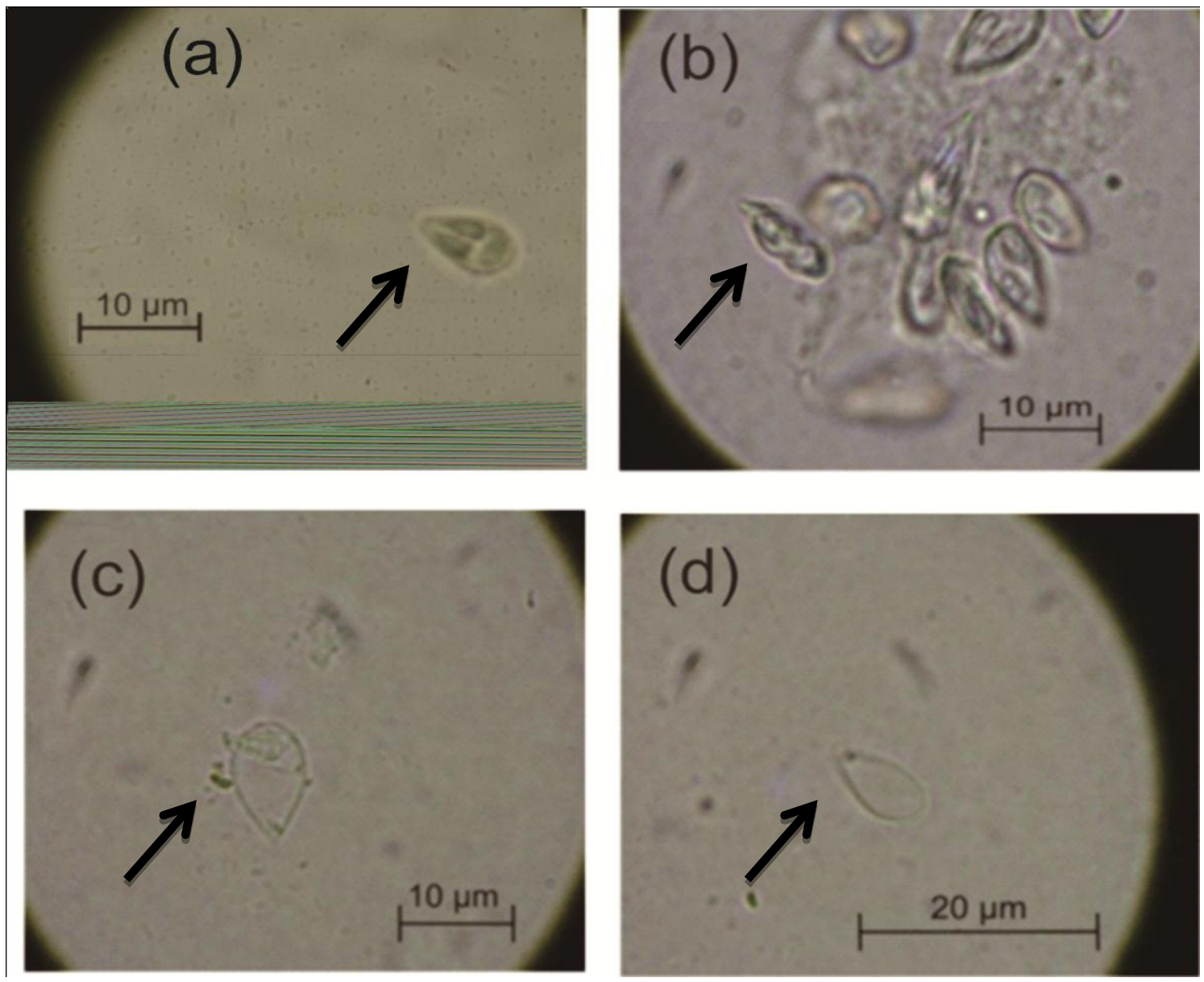

Gambar 1 Spora Myxobolus koi dan beberapa tipe kerusakan spora. Keterangan : a) Spora yang masih utuh (tidak rusak), b) Spora mengkerut, c) kapsul polar dislokasi, d) spora kosong,

Tabel 1 Data Hasil Penyimpanan Spora Myxobolus koi selama 30 hari

\begin{tabular}{cccc}
\hline Perlakuan & $\begin{array}{c}\text { Rerata Spora } \\
\text { Yang Rusak }\end{array}$ & $\begin{array}{c}\text { Rerata Spora Yang } \\
\text { Tidak Rusak }\end{array}$ & Persentase Kerusakan (\%) \pm SD \\
\hline $\mathrm{P}_{1}$ & 63 & 137 & $31,66^{\mathrm{a}} \pm 9,62$ \\
\hline $\mathrm{P}_{2}$ & 68 & 132 & $33,83^{\mathrm{a}} \pm 9,46$ \\
\hline $\mathrm{P}_{3}$ & 51 & 149 & $25,41^{\mathrm{a}} \pm 8,14$ \\
\hline
\end{tabular}

Keterangan : superskrip yang sama pada kolom yang sama menunjukkan tidak adanya perbedaan yang nyata $(\mathrm{p}>0,05)$

$\mathrm{P}_{1}$ : Alkohol $70 \%\left(\mathrm{C}_{2} \mathrm{H}_{6} \mathrm{O}\right)$

$\mathrm{P}_{2}$ : Formaldehida $0,1 \%\left(\mathrm{CH}_{2} \mathrm{O}\right)$

$\mathrm{P}_{3}$ : Kalium bikromat $2 \%\left(\mathrm{~K}_{2} \mathrm{Cr}_{2} \mathrm{O}_{7}\right)$

Kerusakan spora dari tiga perlakuan berkisar 25,41 - 33,83\% dengan jumlah spora tiap sampel sebanyak 200 spora. Rata-rata kerusakan pada $\mathrm{P}_{1}$ (alkohol 70\%) sebesar 31,66\%, $\mathrm{P}_{2}$ (formaldehid $0,1 \%$ ) sebesar $33,83 \%$, dan pada $\mathrm{P}_{3}$ (kalium bikromat 2\%) memiliki rata-rata kerusakan sebesar $25,41 \%$. Rata- rata total kerusakan spora pada tiga perlakuan sebesar 30,3\% dan spora yang tidak mengalami kerusakan sebesar 69,73\%. Hasil uji ANOVA dengan nilai signifikasi yang digunakan adalah 0,05. Tidak ada perbedaan yang nyata dari ketiga perlakuan yakni alkohol $70 \%$ 
$\left(\mathrm{C}_{2} \mathrm{H}_{6} \mathrm{O}\right)$, formaldehida $0,1 \%\left(\mathrm{CH}_{2} \mathrm{O}\right)$, dan kalium bikromat $2 \%\left(\mathrm{~K}_{2} \mathrm{Cr}_{2} \mathrm{O}_{7}\right)$.

Hasil penyimpanan spora menggunakan alkohol $70 \% \quad\left(\mathrm{C}_{2} \mathrm{H}_{6} \mathrm{O}\right)$, formaldehida $0,1 \%\left(\mathrm{CH}_{2} \mathrm{O}\right)$, dan kalium bikromat $2 \%\left(\mathrm{~K}_{2} \mathrm{Cr}_{2} \mathrm{O}_{7}\right)$ selama 30 hari menunjukkan kerusakan spora yang tidak berbeda nyata di setiap perlakuan yang berarti ketiga perlakuan atau ketiga bahan kimia memberikan pengaruh yang sama terhadap spora Myxobolus koi. Hal ini terjadi karena ketiga bahan kimia di atas merupakan larutan fiksatif sehingga dapat mengawetkan spora dengan cara menghentikan proses enzimatif sel tubuh untuk mencegah autolysis. Larutan fiksatif dapat mengkoagulasi protein dengan membentuk senyawa aditif atau dengan mengkombinasi proses koagulasi dan aditif (Kuhlmann, 2009). Dari total jumlah spora terjadi kerusakan sebesar 30,3\% dan spora yang tidak mengalami kerusakan atau masih utuh sebesar sebesar $69,73 \%$, sehingga ketiga bahan kimia dapat digunakan untuk mengawetkan spora Myxobolus koi. Perlu dilakukan uji terhadap spora yang tidak mengalami kerusakan apakah spora tersebut masih infektif terhadap ikan atau sudah mati.

Spora yang rusak pada perlakuan alkohol $70 \%$ dan formaldehid $0,1 \%$ mengalami pengerutan, hal ini berhubungan dengan sifat alkohol. Alkohol $70 \%$ pada dosis tertentu dapat mengkoagulasi protein dan presipitasi glukogen yang menyebabkan spora tidak mendapatkan asupan protein sehingga spora tidak dapat tumbuh dan berkembang. Hal itu tersebut mengakibatkan struktur dinding spora menjadi rusak, selain itu alkohol memiliki daya dehidrasi yang dapat menyerap cairan di dalam spora sehingga kadar air di dalam spora menjadi lebih rendah, akibatnya spora menjadi mengkerut (Nowacek, 2012). Hal yang serupa terjadi pada formaldehid $0,1 \%$, mekanismenya sama yaitu dapat menyerap cairan dan mengeraskan spora. Larutan formaldehid adalah desinfektan yang efektif melawan bakteri vegetatif, jamur, atau virus, tetapi kurang efektif melawan spora bakteri. Formaldehid bereaksi dengan protein, dan hal tersebut mengurangi aktivitas mikroorganisme. Efek sporosidnya yang meningkat tajam dengan adanya kenaikan suhu. Formaldehida bereaksi dengan protein sehingga membentuk rangkaian-rangkaian antara protein yang berdekatan. Akibat dari reaksi tersebut protein mengeras dan spora menjadi mengkerut. Formaldehid memiliki sifat penetrasi, tetapi gerakan penetrasinya lambat sehingga walaupun formaldehida dapat digunakan untuk mengawetkan spora tetapi tidak dapat melindungi secara sempurna (Nowacek, 2012). Formaldehid mampu berpenetrasi hingga pada area yang sulit dijangkau, dan sangat efektif terhadap sebagian besar jenis mikroorganisme, termasuk spora di atas suhu $20^{\circ} \mathrm{C}$. Kalium bikromat sebagai larutan fiksatif adalah sama yaitu menghambat kerusakan spora selama penyimpanan, perbedaannya ada pada mekanisme kerjanya. Kalium bikromat dapat mengawetkan dan mempertahankan struktur protein tanpa mempresipitasi protein tersebut, sehingga pada perlakuan kalium bikromat tidak terjadi pengerutan spora. Kalium bikromat memiliki daya penetrasi sehingga dapat mengawetkan nucleus dan mitokondria. Kalium bikromat dengan konsentrasi 2,5\% digunakan sebagai media sporulasi atau sebagai larutan fiksatif karena pada konsentrasi $2,5 \% \mathrm{pH}$ yang dihasilkan stabil, pada konsentrasi 4,6\% kalium bikromat efektif mengawetkan kromosom karena pada kadar asam yang rendah dapat menjaga struktur sitoplasma sel (Casselman, 1955).

\section{KESIMPULAN DAN SARAN}

Berdasarkan hasil penelitian tentang pengaruh penyimpanan pada berbagai bahan kimia terhadap kerusakan spora Myxobolus koi dapat diambil kesimpulan bahwa ketiga perlakuan yang diberikan yaitu alkohol $70 \% \quad\left(\mathrm{C}_{2} \mathrm{H}_{6} \mathrm{O}\right)$, formaldehida $0,1 \%\left(\mathrm{CH}_{2} \mathrm{O}\right)$, dan kalium bikromat $2 \% \quad\left(\mathrm{~K}_{2} \mathrm{Cr}_{2} \mathrm{O}_{7}\right)$ tidak terjadi 
perbedaan yang nyata yang berarti ketiga bahan kimia dapat digunakan untuk mengawetkan spora Myxobolus koi.

Diperlukan penelitian lebih lanjut untuk menentukan konsentrasi yang paling efektif pada alkohol $\left(\mathrm{C}_{2} \mathrm{H}_{6} \mathrm{O}\right)$, formaldehida $\left(\mathrm{CH}_{2} \mathrm{O}\right)$, dan kalium bikromat $\left(\mathrm{K}_{2} \mathrm{Cr}_{2} \mathrm{O}_{7}\right)$. Perlu penelitian lebih lanjut untuk mengetahui apakah spora Myxobolus koi yang telah disimpan dan tidak mengalami kerusakan masih bersifat infektif terhadap ikan dan pengaruh bahan kimia tersebut terhadap perkembangan spora.

\section{DAFTAR PUSTAKA}

Anshary, H. 2008. Modul Pembelajaran Berbasis Student Center Learning (SCL). Lembaga kajian dan pengembangan pendidikan Mata Kuliah Parasitologi Ikan. Fakultas Ilmu Kelautan dan Perikanan. Universitas Hasanuddin. Hal 38.

Bruce, C.W.G. 1955. Cytological Fixation by Chromic Acid and Dichromates. present address, The Banting and Best Department of Medical Research, University of Toronto, Toronto, Canada. Hal. 203-221.

Jamie M. Nowacek. 2012. Fixation and Tissue Processing. Chapter 16. Fixative. America. 141-152 pp.

Klinger, R. and R.F. Floyd. 2009. Introduction to Freshwater Fish Parasites. University of Florida. 13 hal.

Leiro, J.M., C. Piazzon., B. Dominguez., N. Mallo., J. Lamas. 2011. Evaluation Of Some Physical and Chemical Treatments for Inactiviting Microsporidian Spore Isolated From Fish. Santiago de Compostela. Intern $\mathbf{J}$ of Food Microbio. Elsevier. 156 : 152160.
Titis, C.D., W.S.D. Nugroho, D. Daenuri, H. Nurul dan Sumayani. 2009. Laporan Uji Coba Identifikasi dan Penentuan Derajat Kerusakan Akibat Infeksi Myxobolus sp. pada Ikan Mas (Cyprinus carpio). Balai Karantina Ikan kelas II Tanjung Emas Semarang.

Wolf, D.K. 2009. Fixative. Division of Radiooncology, Deutsches Krebsforschungszentrum, 69120 Heidelberg. Germany. 